\title{
Children and Adolescents with Cancer: Experiences with Chemotherapy ${ }^{1}$
}

\author{
Elizelaine de Chico Cicogna $^{2}$ \\ Lucila Castanheira Nascimento ${ }^{3}$ \\ Regina Aparecida Garcia de Lima ${ }^{4}$
}

\begin{abstract}
This study aimed to comprehend chemotherapy from the perspective of children and adolescents with cancer. Ten children and adolescents between eight and 18 years of age, in different phases of chemotherapy, participated in this exploratory, qualitative study. Data collection was carried out through semi-structured interviews and analysis of the patients' medical records. Analysis of the empirical material followed the content analysis technique. The study allowed the comprehension that, for the children and adolescents, chemotherapy is mainly remembered for its collateral effects and suffering. After the initial impact, mainly due to physical changes, preoccupations are related to disease recovery, i.e. a cure. Over time, they also mentioned that the disease was seen as something to be overcome and, due to the chemotherapy, likely to be the outcome.
\end{abstract}

Descriptors: Neoplasms; Drug Therapy; Child; Adolescent; Pediatric Nursing.

Escola de Enfermagem de Ribeirão Preto, Universidade de São Paulo, WHO Collaborating Centre for Nursing Research Development, SP, Brazil:

1 Paper extracted from Master's Thesis "Crianças e adolescentes com câncer: experiências com a quimioterapia". Supported by FAPESP Process \#2008/08556-0 and CNPq Process \#472134/2007-8.

${ }^{2}$ RN, M.Sc. in Nursing. E-mail: elizelaine@yahoo.com.br.

${ }^{3}$ RN, Ph.D. in Nursing, Full Professor. E-mail: lucila@eerp.usp.br.

${ }^{4}$ RN, Ph.D. in Nursing, Professor. E-mail: limare@eerp.usp.br.

Corresponding Author:

Regina Aparecida Garcia de Lima

Universidade de São Paulo. Escola de Enfermagem de Ribeirão Preto.

Av. dos Bandeirantes, 3900

Bairro Monte Alegre

CEP: 14040-902 Ribeirão Preto, SP, Brasil

E-mail: limare@eerp.usp.br 


\section{Crianças e adolescentes com câncer: experiências com a quimioterapia}

Objetivando compreender como a terapêutica quimioterápica é vista pelas crianças e adolescentes com câncer, participaram deste estudo exploratório de abordagem qualitativa 10 crianças e adolescentes, entre oito e 18 anos, em diferentes momentos da quimioterapia. Para a coleta dos dados, utilizou-se como instrumentos a entrevista semiestruturada e os prontuários. A análise do material empírico seguiu a técnica de análise de conteúdo. O estudo permitiu compreender que, para as crianças e adolescentes, a quimioterapia é lembrada, principalmente, por seus efeitos colaterais, acompanhado de sofrimento. Passado esse primeiro impacto, sobretudo das alterações físicas, as preocupações dirigem-se à recuperação da doença, ou seja, à cura. Com o tempo, relatam que a doença foi vista como algo a ser vencido e, graças à quimioterapia, passível de tal desfecho.

Descritores: Neoplasias; Quimioterapia; Criança; Adolescente; Enfermagem Pediátrica.

\section{Niños y adolescentes con cáncer: experiencias con la quimioterapia}

Objetivando comprender como la terapéutica de quimioterapia es vista por los niños y adolescentes con cáncer, participaron de este estudio exploratorio de abordaje cualitativo, 10 niños y adolescentes entre ocho y 18 años, en diferentes etapas de la quimioterapia. Para la recolección de datos, utilizamos como instrumentos la entrevista semiestructurada y las fichas médicas. El análisis del material empírico siguió la técnica de análisis de contenido. El estudio permitió comprender que, para los niños y adolescentes, la quimioterapia es recordada, principalmente por sus efectos colaterales, acompañado de sufrimiento. Pasado este primer impacto, principalmente el de las alteraciones físicas, las preocupaciones se dirigen a la recuperación de la enfermedad, o sea, a la cura. Con el tiempo, relatan que la enfermedad fue vista como algo a ser vencido y, gracias a la quimioterapia, pasible de obtener ese resultado.

Descriptores: Neoplesias; Quimioterapia; Niño; Adolescente; Enfermería Pediátrica.

\section{Introduction}

Although rare in absolute numbers compared to the incidence in adults, childhood and adolescent cancer has shown an increase in incidence rates ${ }^{(1)}$. Once considered an acute and fatal disease, cancer today has characteristics of a chronic disease and, even with a good prognosis the family and child feel threatened with death when given the diagnosis(2).

There are several treatment modalities and, among them, chemotherapy is the most frequently employed, associated or not with other therapies. The treatment protocol is established according to tumor type, its biological behavior, location, extent of disease, age and general condition of the patient ${ }^{(1)}$.

Chemotherapy promotes a series of transformations in the lives of those who receive it, their body, emotional state and their routines change, concurrently with those of their families. Collateral effects may arise according to the drug and the dose used, however, the most frequent are: apathy, loss of appetite, weight loss, alopecia, bruising, epistaxis and mouth bleeds, mucositis, nausea, vomiting and diarrhea. Another collateral effect is neutropenia, which significantly increases the risk of morbidity and mortality due to infectious processes ${ }^{(3)}$. In this experience they live with feelings of sadness, fear, anxiety and depression, however, despite the adverse effects, chemotherapy is regarded as a source of life ${ }^{(4)}$.

Due to the great influence of the disease and treatment on the lives of children and adolescents with cancer and their families, issues related to quality of life stand out as a priority. In a study that aimed to identify, from the 
perspective of children and adolescents with cancer, issues important to their quality of life, from the qualitative analysis of deepening interviews, four major themes were produced, which were: loneliness, isolation and loss of a normal childhood, decreased enjoyment of food, physical discomfort and disability and, finally, emotional responses to cancer, specifically anger and fear(5).

The patients' perspectives become important and should be considered, since they are the principal experts in their needs related to wellbeing and human values $^{(6)}$. In this sense, health professionals need to understand the experience of the disease, seeking as a source of information, in the case of study, the child or adolescent. This experience needs to be understood from the perspective of those who live it so that they can be helped to find new ways of living well(7).

Giving voice to children and adolescents, however, has not been a common practice in research and in the production of health care $^{(8)}$. Thus, considering chemotherapy as a source of preoccupation, questions and doubts(2), the purpose of this study was to comprehend, from their own statements, how children and adolescents with cancer undergo this experience.

\section{Methodological framework}

This was a qualitative, exploratory study. Observing the legislation regulating human research, the research protocol was approved by the Research Ethics Committee of the Clinical Hospital of the Faculty of Medical of Ribeirão Preto, University of São Paulo (HCFMRP - USP), protocol no. 2399/2008.

The institution selected for the study was a teaching hospital, which is a reference in oncopediatric care, located within the State of São Paulo. The service receives children and adolescents for monitoring in inpatient and outpatient units, with chemotherapy taking place in the inpatient unit and in the chemotherapy center, located in the outpatient clinic.

For the selection of study participants, in the case of the chemotherapy center, the weekly listing of children and adolescents who would undergo the procedure was used. From this list, which contained information such as name, registration number, age, diagnosis, protocol, and the day of chemotherapy, those who met the age criterion (age seven to 18 years) were selected. With respect to the hospitalized children and adolescents daily consultation in the service was carried out, seeking those who met the inclusion criteria (age and chemotherapy procedure).
Ten children and adolescents between eight and 18 years of age, participated in the study, predominantly aged between 15 and 18 years $^{(7)}$ with various cancer diagnoses, all undergoing chemotherapy during the of data collection period. It should be noted that participants were in various phases of treatment, which allowed the inclusion of children and adolescents in the initial stages, as in the case of the adolescent who was experiencing the second cycle of chemotherapy, and others in the maintenance phase or with relapse of the disease.

Our option for children and adolescents in this age group is justified by the fact that they have non-verbal communication skills and manage to comprehend and to express their feelings verbally as a function of the developmental stage in which they are ${ }^{(9)}$.

After identification of patients who met these criteria, it was necessary to establish the link between the researcher and the study participants and their families for the invitation to participate in the study to be presented to them. The approach with children and adolescents occurred in different ways depending on their reactions, either through informal conversations and frequent visits, or through the performance of ludic activities (such as memory games, games with playing cards, chess and painting activities, among others).

For the empirical data collection, the semistructured interview was used and recorded, which was composed of two parts: the first containing information on identification of research participants (gender, age education, religion, diagnosis, therapeutic regimen, duration of treatment and chemotherapy protocols) and the second containing guiding questions that sought the understanding of the therapy (tell me what you know about chemotherapy; what are your feelings while undergoing chemotherapy?; tell me about situations that bother you during treatment; and what could be done by the health team to help you during chemotherapy?).

The interviews took place in periods between chemotherapy cycles or immediately before the infusion, because, during the administration of chemotherapy, the children and adolescents were less responsive and unwilling to bond.

Regarding the location of the interviews, these took place at the sites indicated by the children and adolescents, some in the inpatient unit in situations in which they were hospitalized and others in the chemotherapy center or in the waiting rooms of the clinics. In the different situations the principle of privacy was respected. It is highlighted that there was no compromise in the quality of recording regardless 
of the location of data collection. Study participants were interviewed individually and, conforming to their preference, with or without the presence of the adult responsible, however, when present, the interview was directed toward the child or adolescent. Three interviews had to be supplemented, due to, the information being insufficient for comprehending the experience of chemotherapy for those study participants.

To ensure the anonymity of the children and adolescents in the study, their names were replaced by the letters A through J, in the order in which the interview was conducted, followed by their age.

The empirical material produced from the interview, supplemented by medical record data (protocols adopted, changes in treatments and complications), was typed and organized into individual files, and the analysis followed the steps recommended for the thematic analysis of content, i.e. pre-analysis (reading the empirical material seeking to map the meanings attributed by the subjects to the questions posed), analysis of the expressed and latent meanings (identification of units of meaning), elaboration of the thematics (synthesis of the empirical data) and analysis conclusion (discussion of the thematics). We opted not to statistically analyze the empirical material, as originally advocated by the technique, but to treat it in a comprehensive way, seeking to discover what was behind the manifested content ${ }^{(10)}$. Thus, the data were grouped around three themes: the diagnostic itinerary, the chemotherapy and the support network. Considering the aim of this study, the second theme, i.e. the chemotherapy, is presented organized into the following topics: the impact of the chemotherapy and characteristics of the chemotherapeutic agents.

\section{Results and Discussion}

\section{Impact of the chemotherapy}

To give voice to the children and adolescents with cancer it was found that their experiences were different from each other, but all linked by a common experience, i.e. the experience with chemotherapy at distinct times.

In this sense, from the empirical material it can be seen that chemotherapy was remembered for the short time between diagnosis and treatment. Prior to adapting to the disease and comprehending the process experienced the patients were already are obligated to undergo treatment:

I was hospitalized without knowing anything and they already put me on medication. They came saying: 'Have you already done chemo?' I did not understand any of that (A. 16 years). I had fever and sore throat for a week, so I did the blood test, they thought it was mononucleosis, then I did the myelogram. I came straight to the hospital and at the same time that they discovered, two hours later I was already here doing chemotherapy (E. 15 years).

Some expressed dissatisfaction in situations inherent to treatment, such as hospitalization and the submission to procedures hitherto unknown:

I didn't know what it was, I was quiet, then my dad explained to me I had to do surgery, my hair would fall out and $I^{\prime} d$ stay more in the hospital until the end of the treatment, five years. I started crying because I had never been hospitalized since when I was little, I had never been on a drip, I had only taken saline by mouth and then they said that I would stay longer in hospital, then it was all over, I'll have to stay in the hospital, live in the hospital (C. 11 years). What did I think? Not nice, I didn't know what that was. I was told they would prick my vein, I did not know what they were going to use, I saw the needle and started to cry (D. 8 years).

To seek health care was, until then, sporadic for the study participants. However, chemotherapy brought to them the necessity of protective isolation, which caused the separation from family and for them to frequently be close to hospital units.

The isolation of the children and adolescents was intensified at certain periods after chemotherapy. As well as having visiting restrictions in order to prevent possible infections, they also had to stop attending certain places they were accustomed to, such as school. Often, children are isolated due to severe neutropenia, either in hospitals or at home, which leads to feelings of loneliness and boredom for having to stay, sometimes, all day in $\operatorname{bed}^{(5)}$.

The hospital is seen as an undesirable place, acceptable only when there is no other possibility for the improvement of their condition:

I never want to be hospitalized again, only if I need it very much, otherwise do not ask me to stay in the hospital, I'm not going to. I will never more stay in the hospital (B. 13 years). It's horrible, I stayed 42 days [hospitalized] the first time and then I stayed another 12 after they discovered the treatment. We stay one day locked in our house when it rains and my God, there are people who are hospitalized and stay 42 days in hospital taking medicine, cannot go anywhere, so this is difficult. I stayed sometimes, but I do not like to stay hospitalized no (J. 18 years).

Hospitalization is seen as an anxiogenic situation for the child and family, which may be reflected in the future, depending on the length and frequency of it, the severity of the disease, the medical procedures, the 
adaptive capacity, the level of physical, cognitive and emotional development and the family relationship. From the perspective of the child and adolescent, the hospital has a characteristic of duality, while at the same time that it causes suffering, it also represents a place of healing, where they go to seek medical treatment and examinations, seeking to save their lives and regain their health(11).

The pain felt during the invasive procedures, reinforces feelings of fear, including fear of death:

I did a bone marrow biopsy at the beginning of chemotherapy and a biopsy here [neck], but the bone marrow hurt more, the needle broke and it hurt, it hurt a lot. Now I already wonder, that when I am cured, I will have to do a new bone marrow biopsy, I wonder if it's going to hurt because it hurt a lot, I was afraid. I'm afraid of something happening, I die there on the table because it hurt a lot ( $\mathrm{H} .16$ years).

A study aiming to explore and describe the symptoms of infantile-juvenile cancer, from the perspective of Canadian children and adolescents and their families, found that pain was a symptom present in their quotidian lives, whether the pain resulting from invasive procedures, treatment or from the cancer itself, which reinforces the natural suffering from the disease. The physical and mental exhaustion, fear and unrest that the process caused in the children, the adolescents and the families, reinforces the uncertainties of life faced with cancer, making it more painful(12).

The games, due to the therapy experienced, become restricted and usually those of greater physical impact, such as hide and seek and tag, disappear from their day to day routines. To go out and play with friends no longer makes up part of the routine of the child or adolescent:

I cannot do physical education anymore, play with my friends the way I played, play hide and seek, I cannot run or play squatting boy, which we invented. She [mother] does not let me play outside, does not let me play with my friends, not at home or in the street, she is boring sometimes (D. 8 years). What bothers me is that I cannot do the things that I liked to do like playing football, walking, running, those things I cannot do! Not going to work, I worked (F. 17 years).

The authors point out limitations resulting from the disease and the treatment, such as practicing sports, going to school and going out in the company of friends(5). In another study, the children mentioned a desire to do what other children do such as going to school, making new friends, going to the shopping center and graduating with their $\operatorname{class}^{(13)}$. The school attendance, until then a daily routine of the children and adolescents, becomes less present, since they depend on doctors' authorization to return to school, depending on their treatment phase and their health conditions. The impossibility of attending school prejudices the educational achievement:

I had to quit college and I'm far from everyone, all my friends are there and I'm here alone with my mother, everyone is over there (I. 17 years). I'm only studying here in the hospital. My mom always goes to the school and gets the materials for me, she brings it here and then the teacher here explains it. There in my town we do not have this, if I stay hospitalized, I don't have any school, but here not, here it is different (C. 11 years).

In a review of the literature to investigate the school absences, behavioral problems and social relationships of children with cancer in return to the school, in the UK, it was observed that absences from school are more frequent among children with cancer than among healthy children or with those with other chronic conditions, being a problem from the diagnostic phase until after completion of treatment ${ }^{(14)}$. The children mention the desire to do what other children do such as going to school, making new friends, going to the shopping center and graduating with their class ${ }^{(5)}$.

As much as treatment changes the daily activities of the child and adolescent, the family should seek to maintain the routine prior to diagnosis, so that the sick child will not feel incapacitated, powerless and dependent $^{(2)}$, since the symptoms bring to the children the feeling that the cancer is "more real" in their lives and leads to changes in family routines, including losses and restrictions ${ }^{(12,15)}$.

\section{Characteristics of the chemotherapy}

Chemotherapy was defined by the children and adolescents, in a very brief way, emphasizing primarily the purpose of elimination of the tumor for the cure, being marked by the adverse effects it causes. For them, chemotherapy is a combination of drugs that kill both the bad cells of the tumor cells as well as the good cells (A. 16 years).

It's a lot of drugs. It [chemotherapy] ends up destroying the good cells and bad ones, and then there are the drugs that fight the bad ones and good ones too! I do not know very well! I know that every medicine will cure a part of the body, it seems like I take a pill to combat chemotherapy (H. 16 years). It is a chemical treatment [laughs]. I no longer know, it is a chemical treatment and each one has a certain type, there is the chemical treatment for leukemia, lymphoma, a lot of things, I know that is a chemical treatment (J. 18 years). 
Study participants reported, however, that the first days of intravenous chemotherapy are those with more collateral effects and that, after a few days, they are better disposed:

I became nauseated, vomited, this was only for two days and one day that I was not very good, the rest I did not feel anything (I. 17 years). Gives me vomiting, these things, but soon after I no longer have anything. The body becomes limp, floppy, in the sun the eyes are bad, my stomach hurts! I take medicine, but it does not stop, it doesn't have any effect, I drink cola. Before I was eating a lot, now it's difficult to eat, after a week and I go back to eating again (B. 13 years).

We observed that the collateral effects are the aspect most mentioned by the children and adolescents, with physical changes, the most referred to, because of their relationship with self-image and the integrity of the whole organism. For them, the main collateral effects are discomfort, nausea and vomiting, malaise, poor appetite, weight changes, headaches, skin spots and alopecia. To illustrate:

It [chemotherapy] has some complications, some effects for me were vomiting, headache, noise in the ears. I was feeling the heart beat slower, I even came here because of this, because I was feeling bad, I felt kind of strange, I cannot explain what it was. After and during [chemotherapy] I can't eat anything, just vomiting, headache, these are things that always happen (A. 16 years). Sick, it hurts the stomach, the hair falls out. Some parts have darkened a little [skin] (G. 15 years).

It was found that vomiting can be seen as one of the worst manifestations, favoring loss of appetite, as after eating they commence vomiting, which can lead to the refusal of food during this phase:

I think, it is very bad, vomiting is the worst, it's worse because I hold myself not to throw up, I don't know how. If I start to talk, the sickness comes, especially when I start talking about food, then the stomach starts to turn over. The time that I am hungry, I put something in my mouth, it comes back again, so I am discouraged and don't eat anything else (C. 11 years).

As a result of vomiting and changes in taste, the acceptance of food is greatly diminished. Additionally, changes regarding the preparation and choice of foods to be offered, are incorporated into the domicile practice, however, their acceptance is difficult, which promotes the inclusion of more acceptable food such as ice cream, soft drinks, fruit and others:

Fruit must be washed well and everything boiled or roasted. I do not like candy that has been open for days in the refrigerator or food that does not look good or that I do not know where it came from. I ate these bacteria, now I can see what I eat, I ate fruit without washing my hands, without washing the fruit, I ate in the supermarket [laughs]. I'll change that from now on, there are many bacteria that people eat without noticing (H. 16 years). I can drink soft drinks, ice cream, it's just this that I accept, the rest, everything that I eat, comes back up. I do not like the hospital food, the smell is strong. I wish we had a canteen just for the kids with cancer, I must have a lighter meal because the food here is very strong, those bowls also smell a lot (C. 11 years).

In concordance with the data from this study, authors mention the occurrence, in children and adolescents, of the loss of enjoyment of food due to loss of appetite, changes in taste and even the smell of food. According to the authors, the children described the hospital food as poor and vomit-provoking, suggesting food without smell and even some in particular, uncooked, such as apples, sandwiches and pizza(5).

It was perceived that the periods of chemotherapy are commonly periods of feeling indisposed. At present, the wish for silence, for not communicating and for sleeping or for watching TV, in a passive way is what stands out:

I stay watching TV [while undergoing chemo]. When I'm not watching [television], I'm sleeping (C. 11 years). I sleep just for the time to pass faster (R. 15 years).

Fatigue is a common, complex and multidimensional symptom experienced by most cancer patients during treatment(16). In another study, fatigue is reported by young adults with cancer as the most distressing symptoms they experience from diagnosis to treatment completion ${ }^{(17)}$, influencing the quality of their lives.

With regard to body image, study participants mainly highlighted aspects related to changes in weight and alopecia. The weight loss, more frequent at first, often, beyond troubling the adolescents themselves, becomes more striking due to the comments of others, these comments confer to the weight loss a meaning of attrition due to the treatment. They are changes that influence the self-image of children and adolescents and allow people to perceive that something is happening and interfering with their bodies:

It was not so chubby, I weighed $35 \mathrm{~kg}$, but after the others looked at me, they did not know me anymore because I was losing weight, I became $26 \mathrm{~kg}$. The others saw me and said that I was skinny and I told them it was the chemo. They said, 'Wow, but chemo knocks you down this much?' When I started treatment, I did not eat anything because the fruit had to be cooked and I did not like it, I do not like fruit and then they had to cook the fruit, so I would not eat it. I became really skinny, I felt so ugly and thin. I was crying because, before, every time I 
got on the scales, I was always fatter, the weight just went up, then after when I got on the scales it would only decrease, it was so bad (C. 11 years).

With regard to hair loss, participants mentioned not accepting it at first, since it strongly modifies the selfimage and allows everyone to realize, causing suffering for these children and adolescents. In this phase, they often use, as observed between girls and boys, hats, caps and headscarves, accessories that in some way hide the lack of hair, because for them, alopecia projects an image that is unhealthy:

It is the worst, the worst part is the hair falling out so much. I had long hair, I already cut it a lot, it is falling out a lot. I'm not doing very badly and the hair for us, for a girl, losing hair is not easy. Okay it will grow, but it takes time. It's also bad when you look at yourself and see yourself without hair, this is bad (I. 17 years). Before I was more beautiful, now I'm ugly because I'm bald. When I had hair, my eye was like this, cute, put the hair here and it stayed like this, now I am bald I cannot style it. I put a cloth over my hair to pretend that it was my hair. My mother started calling me naked coconut, my cousin started calling me baldy, it's just my little cousin that is nice, calls me hairy (D. 8 years).

The prejudice causes discomfort, because people often keep away from those that do not fit into "standards of normality", an attitude that can accentuate the feelings of isolation experienced by the children and adolescents ${ }^{(2)}$. As time passes, when they start to worry about other aspects of the treatment, they start to accept the hair loss, realizing that it is a passing, temporary event:

Normal, then it grows again! It all fell out, you run your hand through and are left with tufts of hair in your hand (B. 13 years). The hair is the least problem. If I had it, I would take care of it, I treated my hair very luxuriously, but I lost it because the treatment that we do we have to lose it, so the hair is the least problem, you need health, then hair (11 C. years).

According to the literature, alopecia has psychosocial implications, since the hair is important in social and sexual communication, being a social, cultural and political symbol. Hair loss has been associated with loss of attractiveness and individuality. Thus, the reactions of the patients regarding alopecia can vary following the importance they attach to the hair, the degree of loss, the preparation and information received, and their physical and psychological mechanisms ${ }^{(18)}$.

Often it is in this time of realization of chemotherapy and especially with the appearance of collateral effects, that the child or adolescent perceives themselves as really sick, which is intensified by being restricted during the periods of hospitalization and at home, making the process that they experience even more difficult:

It is really strong, it was then that I realized the reality that I actually had the disease, when my hair began to fall out, but then I saw that it's for my cure, that I need it $(\mathrm{H}$. 16 years). A very bad experience, very bad. I suffered the entire treatment, it is painful. Sometimes it's physical too, but sometimes, you know, I see all my friends leaving, being noisy and me without hair. Sometimes I have no hair, this makes me sad (E. 15 years).

The collateral effects of the drugs cause the children to really perceive themselves as ill and necessitate putting into practice coping mechanisms to live with this new situation ${ }^{(19)}$.

The adolescent participants in the study saw chemotherapy as something that provokes different reactions in the organism, something that certainly could be milder and cause fewer undesirable effects:

The chemo should not do all this damage, it should be just the area it has to interfere with and finish, this would be better (F. 17 years).

At the same time, the collateral effects can also lead adolescents to believe that the chemotherapy is eliminating what is bad, that the treatment is having a good effect toward the cure, stimulating them to continue:

To do and never give up because everything that happens is for your cure. Every time I vomited I thought that now it was going out, I wanted to be cured, that everything bad would leave, it was so. The medicines are strong and being strong they will cure me, if I did not feel anything, how would I know if I was being cured, I'd be in doubt. Today I see that it is from the reaction that they have an effect and by making me vomit I already know this is having an effect inside. (H. 16 years)

Despite the displeasure with the situation, there is a positive attitude toward chemotherapy because they believe that this therapy may be the chance for the recuperation of life ${ }^{(4,20)}$. Contrasting with this idea, the adolescents point to the suffering, during the moments of greatest intensity of the collateral effects of chemotherapy, as responsible for also discouraging the continuation of treatment:

When I get sick it gives me such a thing, sometimes I just want to stop. So I think better, I say: No, I have to fight. But if the person is a weakling, really gets discouraged easily (I. 17 years). The first night I thought that I would not live any longer, I wanted to stop treatment, I just thought, I told my mother that I would talk to the doctor, that I did not want to do anything else. I imagined that if every night was like that, I would not make it, I would give up (H. 16 years). 
In a case study to understand the daily experience of an adolescent girl undergoing chemotherapy for cancer, she mentioned that the lack of control over the adverse effects of the treatment is a cause of concern, anxiety and depression, in addition to inducing a questioning about the continuity of treatment ${ }^{(21)}$.

In the care of children and adolescents with cancer and their families, the plan of nursing care should take into consideration that they will be submitted to long and complex treatment, that they will deal with extensive information about the disease, that they will need to adapt to new people - the health team - who tell them what to do, what to eat and how to act. The nurses responsible for the care of such clients should be in constant training, seeking instruments to meet the physical, emotional, social and cultural necessities of the children, adolescents and their families.

\section{Final considerations}

This study sought to comprehend how the children and adolescents with cancer experience chemotherapy in order to, from their demands and their feelings, identify interventions that can be incorporated into the plan of nursing care directed toward the quality of their lives and their families.

The occurrence of disruption in the quotidian lives of the children and adolescents in the study was observed, given, for example, by the experience with unknown situations, many of them painful and restrictive. Despite the aggressive treatment, the study participants recognize its importance in ensuring their survival and cure.

Remembered primarily for its collateral effects, chemotherapy provoked an immediate and strong impact, making the fear stand out. With the start of chemotherapy infusions, they began to better understand the process, allowing them to define briefly the therapeutic, with prevailing concepts regarding its principle function and its importance for the desired cure.

Habits were changed, restrictions were imposed, isolation from family and friends, unexpected breaks in family routines, and everyday life modified. Even the school attendance became sporadic, depending on the stage of treatment and the conditions of children and adolescents. The body image was another point of impact, especially alopecia and weight loss, due to visually highlighting to other people something different from normal. With the course of treatment, the main concerns emerged from the physical dimensions and reached a plateau directed to evolution and recovery of health, a concern linked to prognosis.

Collateral effects were seen either as responsible for demonstrating the success of the therapy over the disease which encouraged continuity of treatment, or sometimes as discouraging, given the intense suffering they caused. The periods of infusion of chemotherapeutic drugs and the first days that followed were marked by indisposition. They mentioned a strong desire to rest, allowing the fatigue resulting from the experience, either from the disease, the chemotherapy or the hospitalization to be observed.

Thus, nursing professionals, knowing this demand and need of the child and adolescent and knowing that the disease, finally, is seen as something to be beaten, and due to chemotherapy, subject to this outcome, can certainly offer more qualified and targeted nursing assistance.

\section{References}

1. Ministério da Saúde (BR). Instituto Nacional do Câncer. Coordenação de Prevenção e Vigilância do Câncer. Câncer da criança e do adolescente no Brasil: dados dos registros de base populacional e de mortalidade. Rio de Janeiro: Instituto Nacional do Câncer; 2008. 220 p.

2. Costa JC, Lima RAG. Crianças/adolescentes em quimioterapia ambulatorial: implicações para a enfermagem. Rev. Latino-Am. Enfermagem. 2002; 10(3):321-33.

3. Bonassa EMA. Enfermagem em terapêutica oncológica. $3^{a}$ ed. São Paulo (SP): Atheneu; 2005.

4. Cicogna EC. Crianças e adolescentes com câncer: experiências com a quimioterapia. [dissertação]. Ribeirão Preto (SP): Escola de Enfermagem de Ribeirão Preto /USP; 2009. 142 p.

5. Moody K, Meyer M, Mancuso CA, Charlson M, Robbins L. Exploring concerns of children with cancer. Support Care Cancer. 2006; 14: 960-6.
6. Ventafridda V, Scaffidi E, Sbanotto A, Goldhirsch A. Atendimento de apoio e avaliação da qualidade de vida. In: Pollock RE, Doroshow JH, Khayat D, Nakao A, O'Sullivan B. Manual de Oncologia Clínica da União Internacional Contra o Câncer. São Paulo (SP): Fundação Oncocentro de São Paulo; 2006.

7. Jesus LKR, Gonçalves LLC. O cotidiano de adolescentes com leucemia: o significado da quimioterapia. Rev Enferm UERJ. 2006; 14(4):545-50.

8. Rocha EAC. Por que ouvir as crianças? Algumas questões para um debate científico multidisciplinar. In: Cruz SHV, organizadora. A criança fala: a escuta de crianças em pesquisas. São Paulo (SP): Cortez; 2008. p. 43-51.

9. Faux AS, Walsh M, Deatrick JA. Intensive interviewing with children and adolescent. West J Nurs Res. 1988; 10(2): 180-94. 
10. Gomes R. Análise e interpretação de dados de pesquisa qualitativa. In: Minayo MCS, organizadora. Pesquisa social: teoria, método e criatividade. Petrópolis (RJ): Vozes; 2007. p. 79-108.

11. Lemos FA, Lima RAG, Mello DF. Assistência à criança e ao adolescente com câncer: a fase da quimioterapia intratecal. Rev. Latino-Am. Enfermagem. 2004; 12(3):485-93.

12. Woodgate RL, Degner LF, Yanofsky R. A different perspective to approaching cancer symptoms in children. J Pain Symptom Manage. 2003; 26(3): 800-17.

13. Moreira GMS. A criança com câncer vivenciando a reinserção escolar: estratégia de atuação do psicólogo. [dissertação]. Ribeirão Preto (SP): Faculdade de Filosofia, Ciências e Letras de Ribeirão Preto/USP; 2002.

14. Vance $\mathrm{YH}$, Eiser $\mathrm{C}$. The school experience of the child with cancer. Child Care Health Dev. 2002; 28(1):5-19.

15. Pentheroudakis G, Pavlidis N. Late toxicity in survivors from adolescent cancer. Cancer Treat Rev. 2007; 33(7): 609-15.

16. Yeh $\mathrm{CH}$, Chiang YC, Lin L, Yang CP, Chien LC, Weaver MA, et al. Clinical factors associated with fatigue over time in pediatric oncology patients receiving chemotherapy. $\mathrm{Br}$ J Cancer 2008; 99:23-9.
17. Hockenberry M. Symptom management research in children with cancer. J Pediatr Oncol Nurs 2004; 21(3):132-6.

18. Batchelor D. Hair and cancer chemotherapy: consequences and nursing care - a literature study. Eur J Cancer Care. 2001; 10:147-63.

19. Françoso LPC. Vivências de crianças com câncer no grupo de apoio psicológico: estudo fenomenológico. [tese]. Ribeirão Preto (SP): Faculdade de Filosofia, Ciências e Letras de Ribeirão Preto/USP; 2001.

20. McCaughan EM, Thompson KA. Information needs of cancer patients receiving chemotherapy at a day-case unit in Northern Ireland. J Clin Nurs. 2000; 9:851-8.

21. Luisi FAV, Petrilli AS, Tanaka C, Caran EMM. Contribution to the treatment of nausea and emesis induced by chemotherapy in children and adolescents with osteosarcoma. São Paulo Med J. $2006 ; 124(2): 61-5$.

Received: Jul. $18^{\text {th }} 2009$

Accepted: Mar. $3^{\text {rd }} 2010$ 